\title{
DAMAGE TO RIVER DIKES
}

\author{
OSAMU MATSUOi)
}

\begin{abstract}
Among the rivers damaged by the earthquake, two most severely damaged along the Yodo-gawa River are described. In the left levee, the settlement exceeded $2 \mathrm{~m}$ for a length of $1.4 \mathrm{~km}$, with a maximum settlement of $3 \mathrm{~m}$. Sand boils were observed extensively on the ground surface near the damaged dikes. Holocene sandy soil with an SPT Nvalue of 10 or less existed in the upper part of the subsoil profile. These facts indicate that liquefaction of the soil was the major cause of the embankment damage. The cyclic stress ratio required to cause liquefaction was 0.30 as determined from cyclic triaxial tests on undisturbed samples.
\end{abstract}

Key words: earthquake damage, liquefaction, river dike (IGC: D7/E8/E6)

\section{INTRODUCTION}

Flood control river dikes suffered extensive failure. Damage to the dikes consisted of cracking, settlement, lateral spreading and slumping.

Table 1 summarizes the damage to the rivers administered by the central government. The damage was observed on six rivers, amounting to 32 sites and a total length of $9,290 \mathrm{~m}$. The most severely damaged were the dikes of the Yodo-gawa, which, flowing through Osaka, is the largest river in the Kansai area. The Yodo-gawa is not however the closest river to the epicenter. At most of the damaged sites, sand boils were observed on the ground surface near the dikes. Major damage to the Yodo-gawa is described in the following sections of this paper. For details about the location, refer to ref. 1).

Table 1. Summary of damage to river dikes

\begin{tabular}{l|l|c|c}
\hline River & Location & $\begin{array}{c}\text { Number of } \\
\text { damaged sites }\end{array}$ & $\begin{array}{c}\text { Total length of } \\
\text { damaged sites (in m) }\end{array}$ \\
\hline Yodo-gawa & Osaka Pref. & 18 & 6,590 \\
\hline Kanzaki-gawa & Osaka Pref. & 1 & 30 \\
\hline Ina-gawa & Hyogo Pref. & 3 & 610 \\
\hline Mo-kawa & Hyogo Pref. & 5 & 680 \\
\hline Kako-gawa & Hyogo Pref. & 3 & 1,180 \\
\hline Yura-kawa & Kyoto Pref. & 2 & 200 \\
\hline \multicolumn{2}{c|}{ (Total) } & 32 & 9,290 \\
\hline
\end{tabular}

\section{TORISHIMA DIKE AT YODO-GAWA}

A length of $2,000 \mathrm{~m}$ (kilopost $0.2-2.2 \mathrm{~km}$ ) of the Torishima Dike, the left levee of the Yodo-gawa, was severely damaged. The dike was designed to protect against the high sea tide of $5.2 \mathrm{~m}$ above mean sea level. The core of the dike was a soil embankment, and the river side surface was protected by concrete parapet wall, the design height of which was $8.1 \mathrm{~m}$ from the sea level. The rear slope and the top were faced with concrete blocks and asphalt pavement, respectively.

Photograph 1 shows the damage and Fig. 1 shows the maximum settlement of the embankment crest due to the shaking. The cross section is illustrated in Fig. 2. The concrete parapet at the top of the levees tilted and settled. The parapet slid about $8 \mathrm{~m}$ into the river. The embankment also settled and cracked severely. The settlement exceeded $2 \mathrm{~m}$ on the kilopost $0.5-1.9 \mathrm{~km}$, with a maximum of $3 \mathrm{~m}$. Sand boils along the fissures were observed on the ground surface along the dike. Lateral movements and heaving of the ground surface occurred in the residential area where the ground elevation was low. These facts suggest that soil liquefaction triggered the damage.

Figure 3 shows the soil profile along the right dike and Fig. 4 shows the cross section at the $1.4 \mathrm{~km}$ kilopost site. These figures were drawn based on boring data obtained after the earthquake, in February and March, 1995. As shown in these figures, the dike is underlain by the Holocene deposit with a thickness of about $30 \mathrm{~m}$, called the Umeda Layer. The deposit consists of, from the top, the upper sandy layer (As2), clay layer (Ac) and the lower

i) Head, Soil Dynamics Division, Public Works Research Institute, Ministry of Construction, Asahi 1, Tsukuba, Ibaraki 305. Manuscript was received for review on August 22, 1995.

Written discussions on this paper should be submitted before August 1, 1996 to the Japanese Geotechnical Society, Sugayama Bldg. 4F, Kanda Awaji-cho 2-23, Chiyoda-ku, Tokyo 101, Japan. Upon request the closing date may be extended one month. 


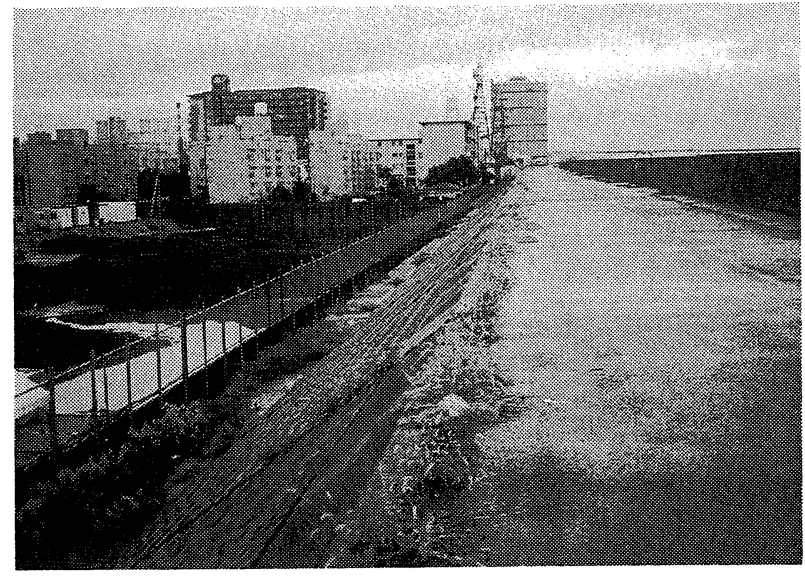

(a)

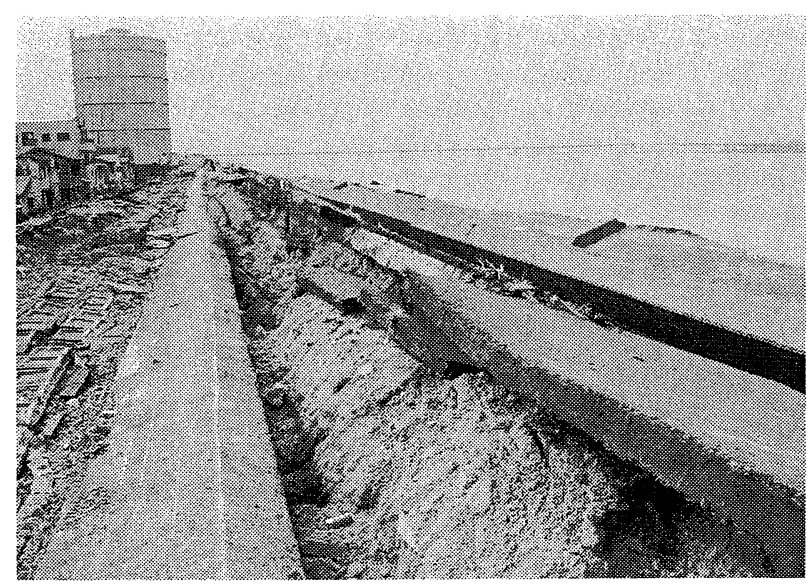

(b)

Photo. 1. Damage to the Torishima Dike: (a) Before the earthquake (Looking downstream from the $1.7 \mathrm{~km}$ site; the Yodo-gawa mainstream is on the right hand side.); (b) After the earthquake (Looking downstream from the $1.4 \mathrm{~km}$ site) sandy layer (As1). The thickness of the Holocene deposit decreases downstream. The As2 layer is also divided into the upper sublayer (As2-2) and the lower sublayer (As21). The SPT $N$-value is less than 10 in the As2-2 layer, and more than 10 in the As2-1 layer. The sand boils observed after the quake are considered to have been ejected from the upper sandy layer.

Figure 5 shows the grain size distribution of the As2-2 layer. Average of the mean grain size and fines content are $0.2-0.3 \mathrm{~mm}$ and $20 \%$, respectively. Cyclic undrained triaxial compression tests were made on samples obtained from the depth of 8.0-8.6 m (As2-2 layer) of the 1.4 k-3 borehole (see Fig. 4). The double tube twist sampler with an inner diameter of $70 \mathrm{~mm}$ and an outer diameter of $97 \mathrm{~mm}$ was used in the sampling. The samples obtained were frozen at the sites and then carried to a laboratory. The test results are presented in Fig. 6. The cyclic stress ratio, $\sigma d / 2 \sigma c^{\prime}$ ( $\sigma d$ : deviatoric cyclic axial stress; $2 \sigma c^{\prime}$ : effective confining stress), required to cause $5 \%$ axial strain in 20 cycles, is about 0.30 .

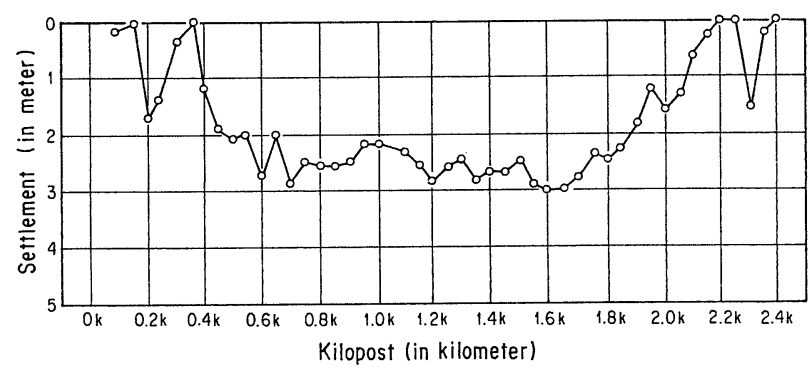

Fig. 1. Settlement of the Torishima Dike

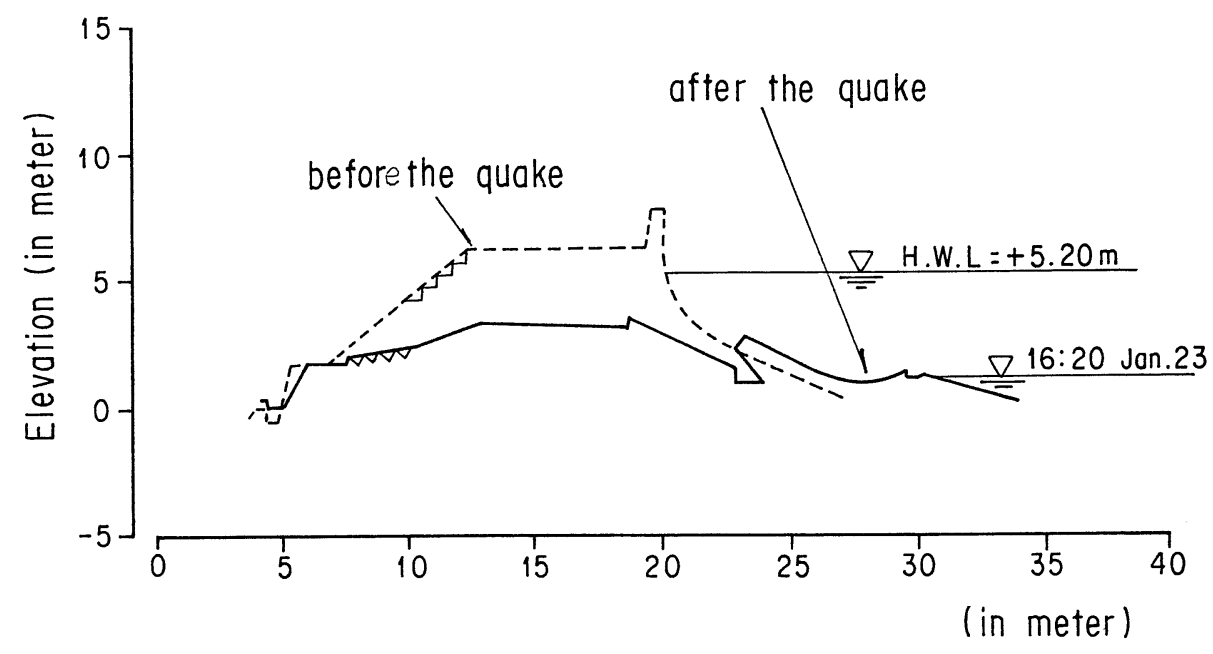

Fig. 2. Cross section of the Torishima Dike 


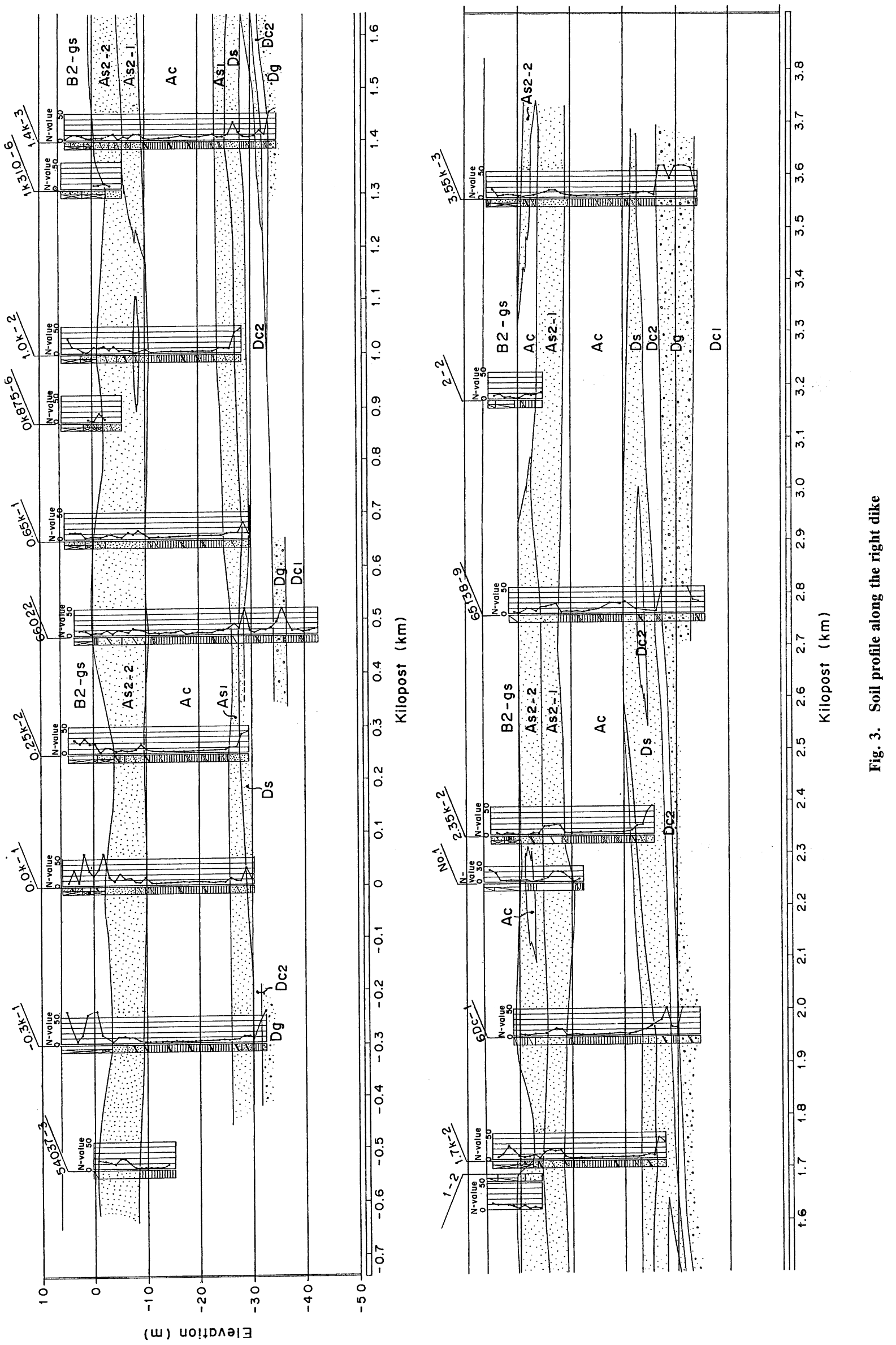




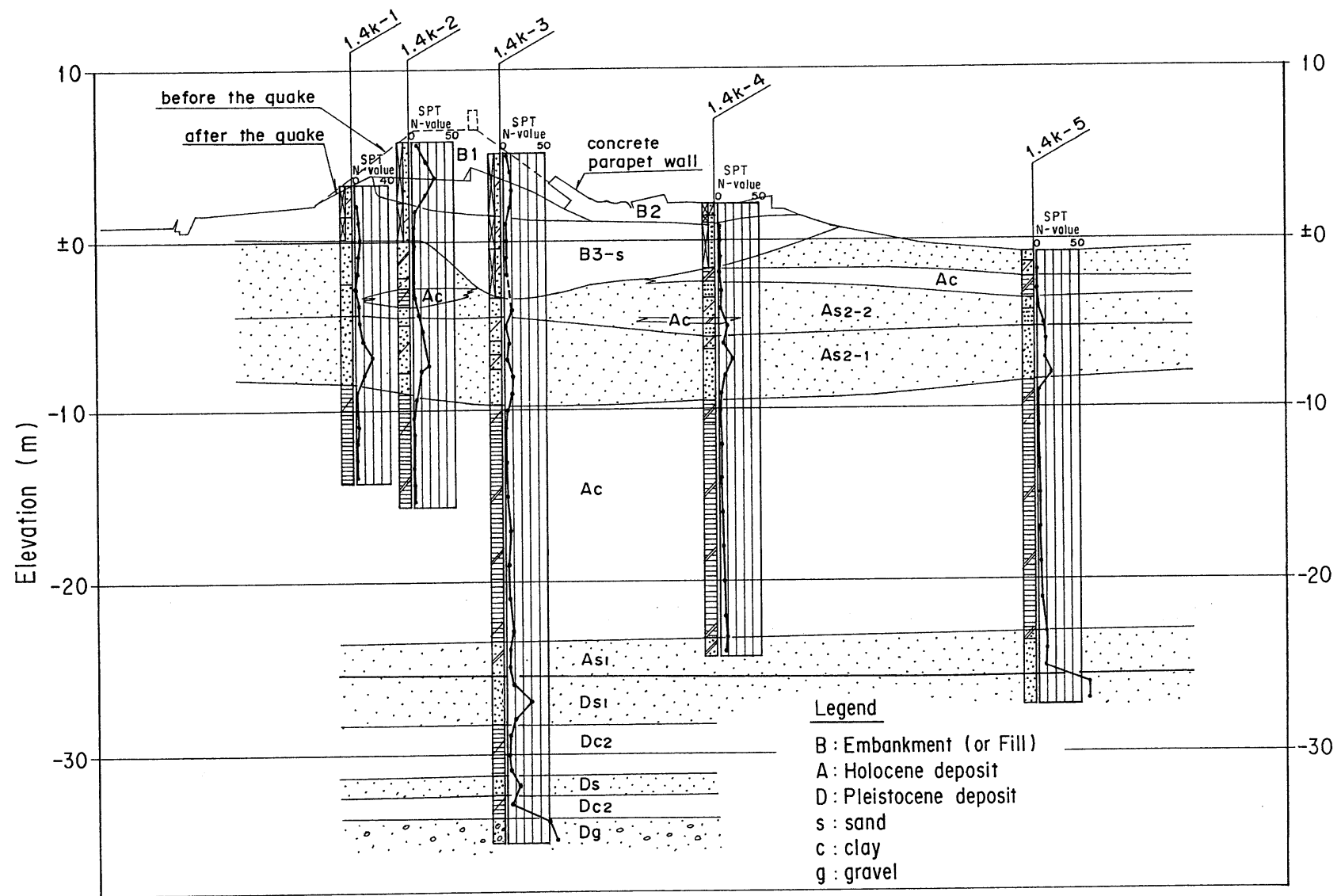

Fig. 4. Cross section and soil profile of the Torishima Dike at kilopost of $1.4 \mathrm{~km}$

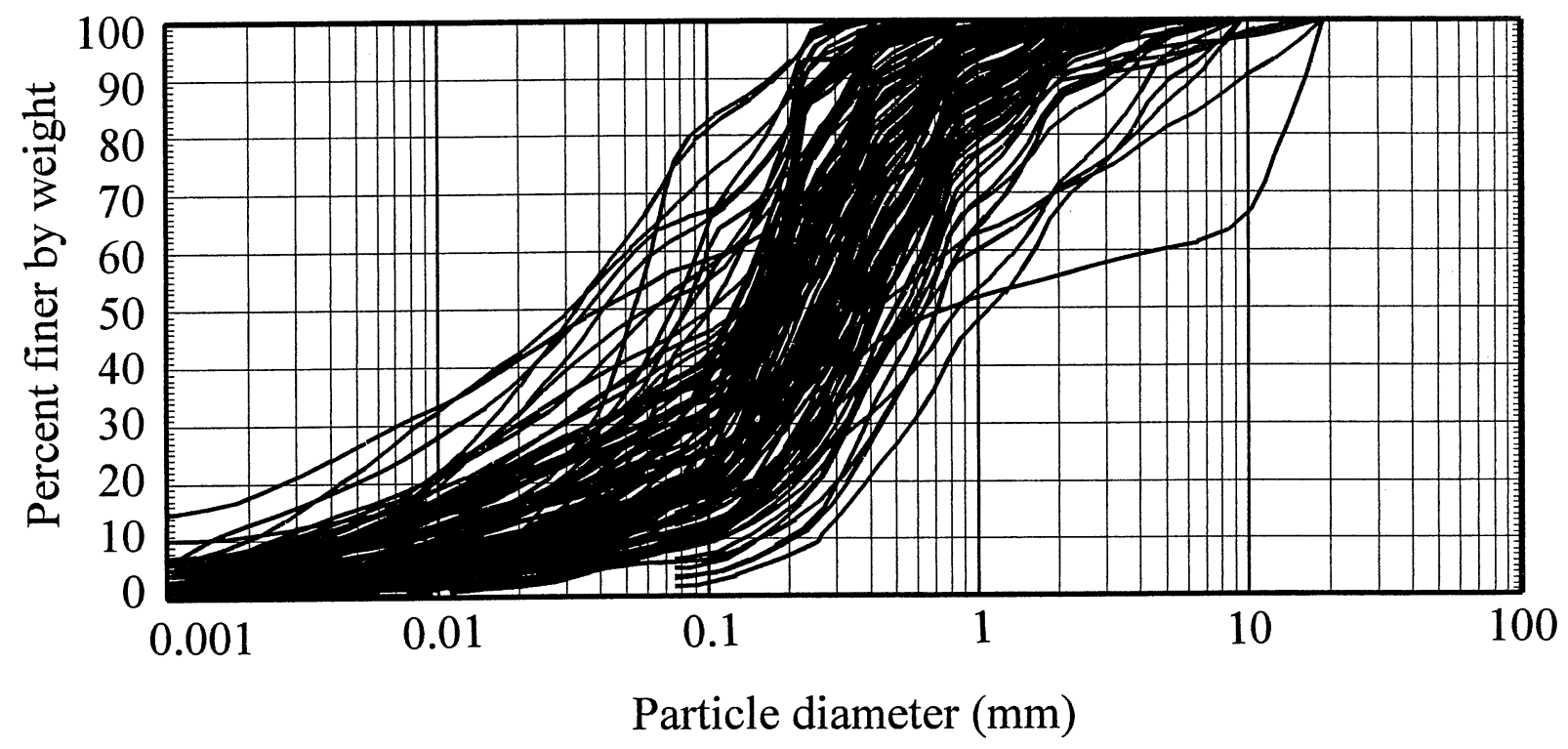

Fig. 5. Grain size distribution of the upper sandy layer, As2, at Torishima

\section{NISHIJIMA DIKE AT YODO-GAWA}

A $750 \mathrm{~m}$ length (kilopost $1.2-2.0 \mathrm{~km}$ ) of the right levee, located just opposite the damaged Torishima Dike, was also damaged. Although the structure of the dike was similar to that of the Torishima Dike, there was no damage to the parapet. Only the embankment slope failure occurred in the rear slope. The crack that developed at the crest was about 20 to $150 \mathrm{~cm}$ wide and its subsidence amounted to $1.2 \mathrm{~m}$ (Photo. 2). The toe of the damaged slope displaced about $1 \mathrm{~m}$. Sand boils were observed near the toe. The cross section of the failed embankment together with the boring data and the soil profile is presented in Fig. 7. At the $1.7 \mathrm{k}-4$ boring loca- 


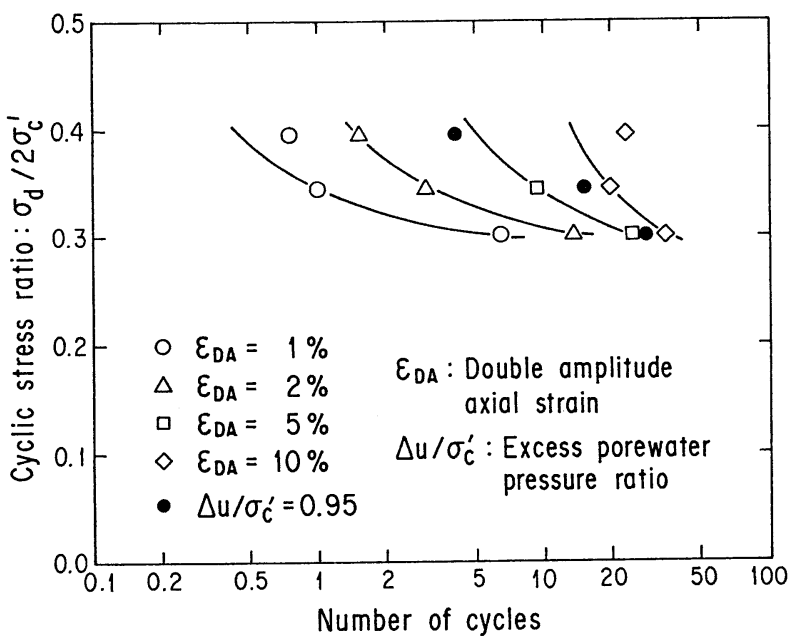

Fig. 6. Liquefaction test results for the upper sandy layer, As2-2, at Torishima

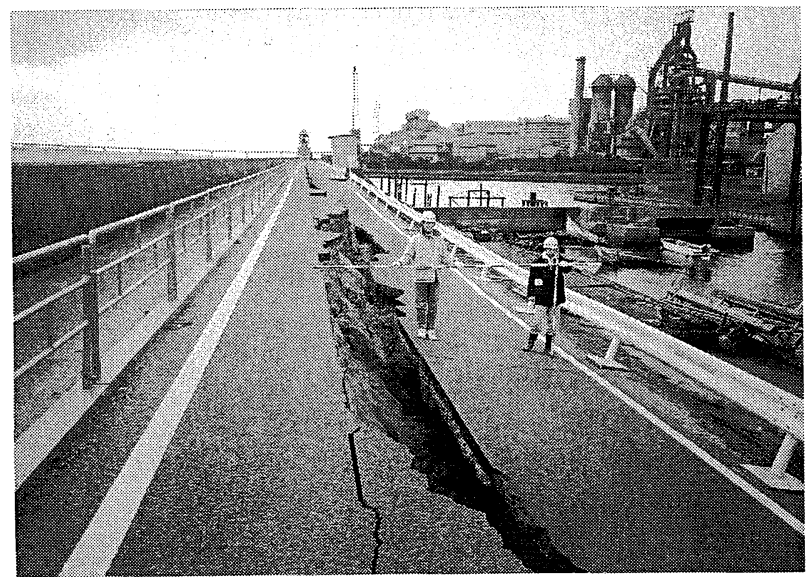

Photo. 2. Damage to the Nishijima Dike (Looking downstream from the $1.7 \mathrm{~km}$ site; the Yodo-gawa mainstream is seen on the left hand side. The water seen in the right hand side is a tributary river.)

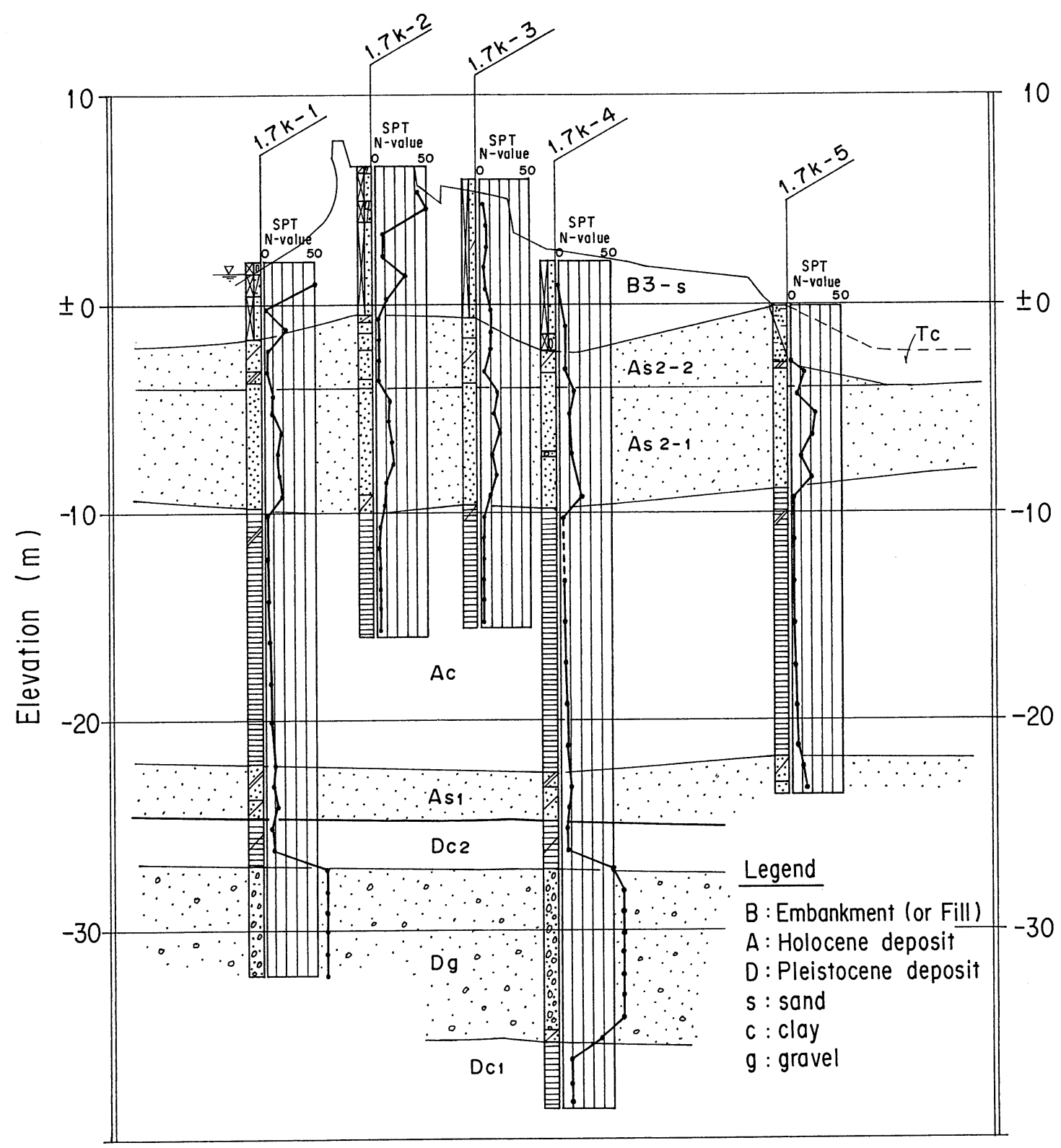

Fig. 7. Cross section and soil profile of the Nishijima Dike at kilopost of $1.7 \mathrm{~km}$ 
tion in this figure, the embankment material seems to have penetrated into the upper sandy layer (As2). This may indicate that the embankment slope failure was induced by the loss of shear strength in the As2 layer, probably due to liquefaction. In Fig. 7, however, no distinct difference in the SPT $N$-value was observed between both sides of the levee; one side failed but the other side did not fail.

Figure 8 plots the results of cyclic undrained triaxial tests on samples obtained from the As2-2 layer. The cyclic stress ratio, $\sigma d / 2 \sigma c^{\prime}$, required to cause $5 \%$ axial

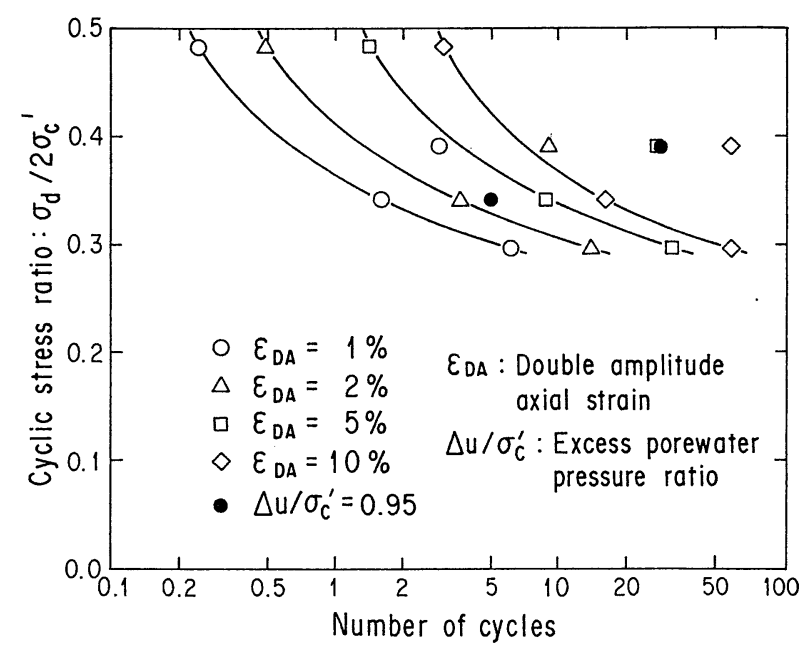

Fig. 8. Liquefaction test results for the upper sandy layer, As2-2, at Nishijima strain in 20 cycles, is about 0.31 , which is almost equal to that obtained at Torishima. No clear difference in the grain size distribution of the As2-2 soil was observed between the two sites.

\section{CONCLUSIONS}

Among the river dikes damaged by the earthquake, data for two most severely damaged sites along the Yodo-gawa River were presented in the paper. The maximum settlement of the embankment was $3 \mathrm{~m}$. Sand boils were observed at most of the damaged sites. Geotechnical survey and laboratory tests conducted immediately after the event revealed that there existed Holocene sandy soil with SPT $N$-value of 10 or less in the upper part of the subsoil profile. These facts indicated that liquefaction of the foundation soil was the major cause of the damage to the embankment.

\section{ACKNOWLEDGEMENT}

All the data presented in this paper was provided by the Yodo-gawa Work Office, Kinki Regional Construction Bureau, Ministry of Construction. The author is grateful for the permission to present the data.

\section{REFERENCE}

1) Takada, N., Nishi, M. and Fukuda, M. (1996): "Damage of River Levees and Revetments," Special Issue of Soils and Foundations on the 1995 Hyogoken-Nambu earthquake, pp. 241-254. 